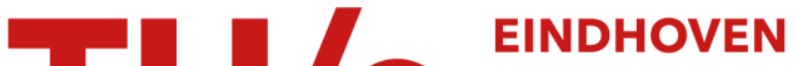 UNIVERSITY OF TECHNOLOGY
}

\section{Dehydrogenative Azolation of Arenes in a Microflow Electrochemical Reactor}

Citation for published version (APA):

Buglioni, L., Beslać, M., \& Noël, T. (2021). Dehydrogenative Azolation of Arenes in a Microflow Electrochemical Reactor. Journal of Organic Chemistry, 86(22), 16195-16203. https://doi.org/10.1021/acs.joc.1c01409

DOI:

10.1021/acs.joc.1c01409

Document status and date:

Published: 19/11/2021

Document Version:

Publisher's PDF, also known as Version of Record (includes final page, issue and volume numbers)

Please check the document version of this publication:

- A submitted manuscript is the version of the article upon submission and before peer-review. There can be important differences between the submitted version and the official published version of record. People interested in the research are advised to contact the author for the final version of the publication, or visit the $\mathrm{DOI}$ to the publisher's website.

- The final author version and the galley proof are versions of the publication after peer review.

- The final published version features the final layout of the paper including the volume, issue and page numbers.

Link to publication

\section{General rights}

Copyright and moral rights for the publications made accessible in the public portal are retained by the authors and/or other copyright owners and it is a condition of accessing publications that users recognise and abide by the legal requirements associated with these rights.

- Users may download and print one copy of any publication from the public portal for the purpose of private study or research.

- You may not further distribute the material or use it for any profit-making activity or commercial gain

- You may freely distribute the URL identifying the publication in the public portal.

If the publication is distributed under the terms of Article $25 \mathrm{fa}$ of the Dutch Copyright Act, indicated by the "Taverne" license above, please follow below link for the End User Agreement:

www.tue.nl/taverne

Take down policy

If you believe that this document breaches copyright please contact us at:

openaccess@tue.nl

providing details and we will investigate your claim. 


\title{
Dehydrogenative Azolation of Arenes in a Microflow Electrochemical Reactor
}

\author{
Laura Buglioni, Marko Beslać, and Timothy Noël*
}

Cite This: J. Org. Chem. 2021, 86, 16195-16203

Read Online

ABSTRACT: The electrochemical synthesis of aryl azoles was performed for the first time in a microflow reactor. The reaction relies on the anodic oxidation of the arene partners making these substrates susceptible for $\mathrm{C}-\mathrm{H}$ functionalization with azoles, thus requiring no homogeneous transition-metal-based catalysts. The synthetic protocol benefits from the implementation of a microflow setup, leading to shorter residence times (10 $\mathrm{min})$, compared to previously reported batch systems. Various azolated compounds ( 22 examples) are obtained in good to excellent yields.

$\mathrm{N}$-Aryl azoles represent an important recurring motif in various biologically active molecules, relevant for medicinal chemistry, ${ }^{1-4}$ and crop-protection science. ${ }^{5}$ Consequently, the $\mathrm{C}-\mathrm{N}$ cross-coupling between arenes and azoles has been widely studied. Traditionally, its synthesis relied on the use of transition metal catalysts, thus requiring prefunctionalized substrates, meticulous ligand design as well as the addition of oxidants and other additives (Scheme 1A). ${ }^{6-19}$ Other possibilities $^{20-22}$ to prepare $N$-aryl azoles include $S_{N} A r$-type reactions for electron-deficient arenes ${ }^{23-25}$ and the use of iodine $^{26,27}$ or hypervalent iodine species. ${ }^{28,29}$

In 2015 , an important photocatalytic $\mathrm{C}-\mathrm{H}$ functionalization methodology using an acridinium salt as photocatalyst was reported by Nicewicz. ${ }^{30}$ The strategy allowed for the regioselective azolation after the initial oxidation of electronrich arenes. After this work, the development of various photocatalytic azolation strategies of arenes was intensified, using a diverse set of homogeneous and heterogeneous photocatalysts (Scheme 1B). ${ }^{31-36}$

As an alternative to photocatalytic oxidation strategies, electrochemical methods ${ }^{37}$ have been developed to enable the amination of $\mathrm{C}(\mathrm{sp})-\mathrm{H},{ }^{38} \mathrm{C}\left(\mathrm{sp}^{2}\right)-\mathrm{H},{ }^{39-43}$ and benzylic $\mathrm{C}\left(\mathrm{sp}^{3}\right)-\mathrm{H}$ bonds. ${ }^{44,45}$ In fact, synthetic electrochemistry offers several advantages compared to traditional synthetic methods: (i) electrons can be considered as traceless reagents, (ii) no external oxidants or homogeneous metal catalysts are needed, and (iii) the selectivity can be tuned via the applied potential. $^{46-49}$ Moreover, many technical issues previously related to electrochemical systems are now considered overcome, spurring renewed interest in electrochemical synthetic chemistry. ${ }^{50}$ Concerning electrochemical azolation reactions (Scheme 1C), several notable strategies have been developed in the past years by the groups of Yoshida, ${ }^{51}$ Devillers, ${ }^{52} \mathrm{Li}^{53} \mathrm{Lei}^{54,55} \mathrm{Wu}^{56}$ and Liu. $^{57}$ Also, electro-

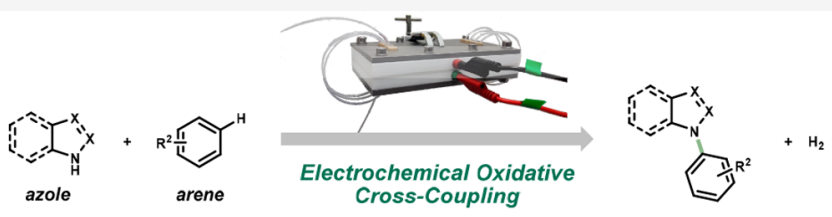

Broad substrate scope - Sustainable - Mild reaction conditions - $10 \mathrm{~min}$ reaction time

photochemical approaches to couple arenes and azoles have been realized by Lambert et al. ${ }^{58}$ and $\mathrm{Hu}$ et al. ${ }^{59}$ (Scheme 1D).

In these batch-based electrochemical transformations, two recurring drawbacks can be distinguished: (i) the need for extended reaction times and/or higher temperatures, which can lead to reduced reaction selectivity; (ii) the transformation is often tailored to a specific class of substrates. ${ }^{55,57}$ Considering these insights, we anticipated that flow technology could possibly alleviate those issues (Scheme $1 \mathrm{E}$ ). Due to the narrow interelectrode gap, the amount of supporting electrolytes can substantially be reduced in electrochemical microreactors. ${ }^{60,61}$ Furthermore, the high electrode surface-tovolume ratio allows for accelerating the reaction rate significantly, leading to reduced reaction times and less sideproduct formation. ${ }^{62,63}$ Here, we describe the first electrochemical dehydrogenative cross-coupling of arenes with azoles in a microflow reactor. ${ }^{64}$

Our initial investigations commenced by subjecting 1,3,5trimethylbenzene and pyrazole as model substrates to the electrochemical transformation in a microflow reactor (see Supporting Information). The electrochemical microflow reactor was equipped with a carbon anode and a stainlesssteel cathode separated by a Teflon gasket, resulting in an interelectrode gap of $250 \mu \mathrm{m}$ and a volume of $700 \mu \mathrm{L}$ (see Supporting Information). ${ }^{65}$ After optimizing various reaction and process parameters (see Supporting Information for full details), $67 \%$ of the desired cross-coupled product 1 could be

Special Issue: Electrochemistry in Synthetic Organic Chemistry

Received: June 14, 2021

Published: August 30, 2021

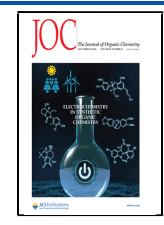


Scheme 1. Recent Developments in the Azolation of Arenes $^{a}$

A) Transition-metal catalysed approach (ref. 6-19)

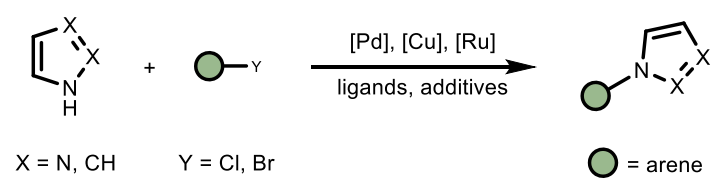

B) Photocatalytic approach (ref. 30-37)<smiles>[X]c1[14cH]cc[nH]1</smiles>

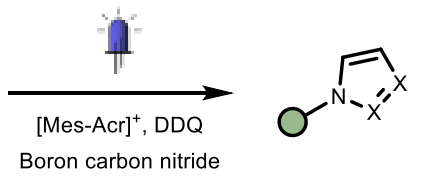

oxidant/co-catalyst

C) Electrochemical approach (ref. 52-57)

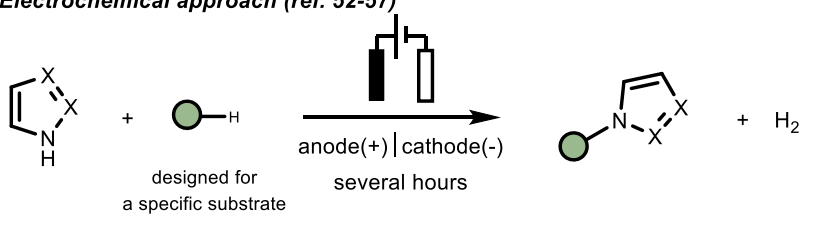

D) Photoelectrochemical approach (ref. 58-59)

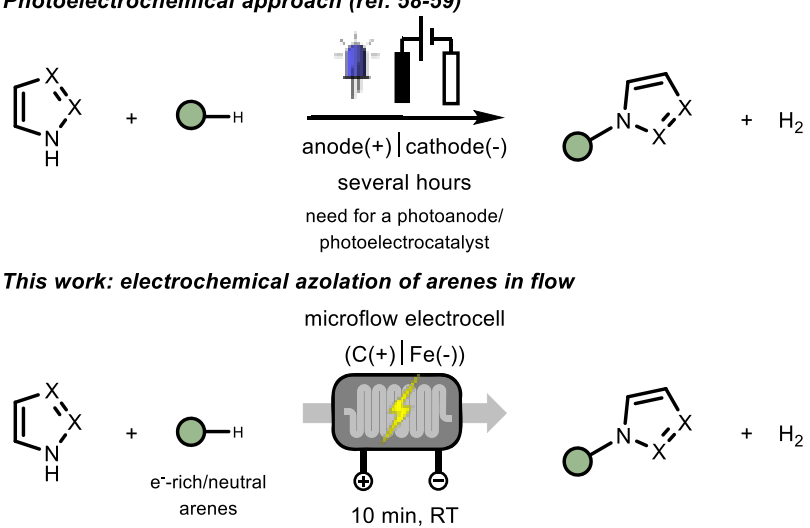

${ }^{a}$ (A) classical coupling reactions enabled by transition metals; (B) photocatalytic approaches; (C) electrochemical strategies; (D) photoelectrochemical approach; and (E) our work on the development of an electrochemical azolation of electron-rich and -neutral arenes in flow.

isolated after exposing a solution of pyrazole and 1,3,5trimethylbenzene (6 equiv) in hexafluoro-2-propanol (HFIP)/ $\mathrm{CH}_{2} \mathrm{Cl}_{2}$ (7:3) for only 10 min to the galvanostatic conditions $\left(20 \mathrm{~mA}\right.$, corresponding to $0.71 \mathrm{~mA} \mathrm{~cm}{ }^{-2}$ and $2.6 \mathrm{~F} \mathrm{~mol}^{-1}$, Table 1, entry 1). Other solvent systems can be used for the electrochemical azolation of arenes without significant reduction in conversion and yield (Table 1, entries 2 and 3 ). However, we found that, during the scope exploration, the combination of $\mathrm{HFIP} / \mathrm{CH}_{2} \mathrm{Cl}_{2}$ (7:3) provided optimal results in terms of conversion, stability, and solubility of the starting materials and the corresponding products. It should be further noted that HFIP is a common solvent in electrochemistry, owing to its acidity, the ability to form hydrogen bonds, and redox stability. ${ }^{66-68}$ Shortening the residence time was detrimental to the reaction outcome, even at higher current densities (Table 1, entries 4 and 5). This might be due to the formation of larger amounts of byproducts. Further, control experiments revealed that electricity is crucial to induce the
Table 1. Optimization of the Reaction Conditions and Control Experiments

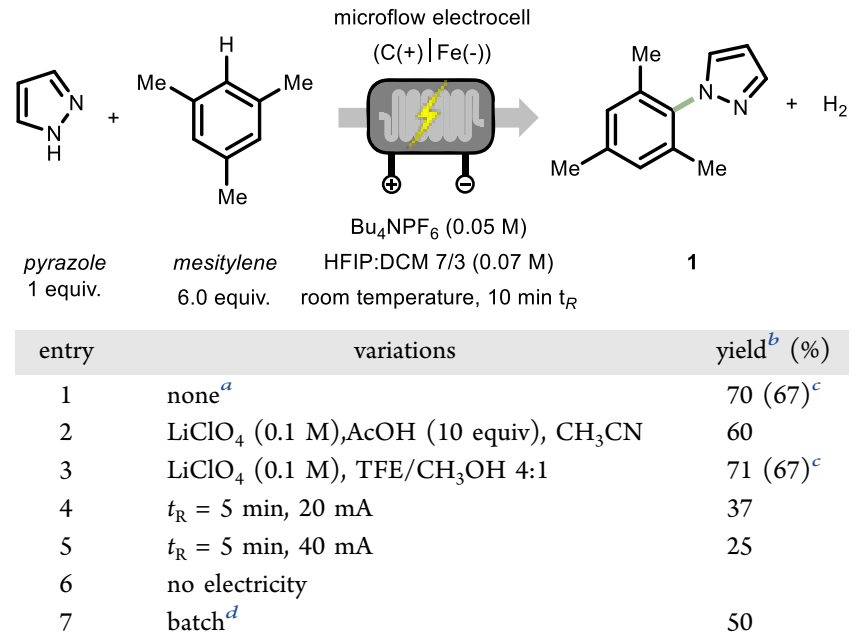

${ }^{a}$ Optimized reaction conditions: pyrazole $(0.67 \mathrm{mmol})$, mesitylene (6.0 equiv), $\mathrm{LiClO}_{4}(0.1 \mathrm{M})$ or $\mathrm{Bu}_{4} \mathrm{NPF}_{6}(0.05 \mathrm{M})$, solvent mixture $(10 \mathrm{~mL})$, graphite anode/Fe cathode, $20 \mathrm{~mA}\left(0.71 \mathrm{~mA} \mathrm{~cm}{ }^{-2}, 2.6 \mathrm{~F}\right.$ $\left.\mathrm{mol}^{-1}\right) .{ }^{b}$ Yield determined by GC-FID with diglyme as an internal standard. ${ }^{c}$ Yield after column chromatography. ${ }^{d}$ Batch reaction conditions: Electrasyn, $7.2 \mathrm{~mA} \mathrm{~cm}$, $2.0 \mathrm{~F} \mathrm{~mol}^{-1}, \mathrm{C}$ anode/Fe cathode, pyrazole $(0.33 \mathrm{mmol}), \mathrm{HFIP} / \mathrm{DCM} 7: 3(5.0 \mathrm{~mL}), \mathrm{Bu}_{4} \mathrm{NPF}_{6}$ $(0.05 \mathrm{M}), 1 \mathrm{~h}$ reaction time.

observed cross-coupling between 1,3,5-trimethylbenzene and pyrazole (Table 1, entry 6). Finally, the reaction was also carried out in batch using a commercially available Electrasyn, resulting in $65 \%$ conversion, with $50 \%$ yield for target compound 1 after $1 \mathrm{~h}$ (Table 1, entry 7), despite the higher current density. ${ }^{61}$

With the optimal conditions in hand, we sought to evaluate the generality of this flow-based electrochemical azolation protocol (Scheme 2). Various electron-neutral arenes could be coupled with pyrazole in good to excellent yields (1-4, 45$90 \%$ yields). Product 1 was obtained in $76 \%$ yield $(219 \mathrm{mg}$ ), and also $34 \%$ of the mesitylene starting material could be recovered after column chromatography. The reaction is not particularly sensitive to steric hindrance as showcased by compounds 1 and 4. Arenes bearing a free hydroxyl moiety can be readily coupled with pyrazole yielding the targeted cross coupled product in an excellent yield (5, 98\% yield). When 1,3,5-methoxybenzene was used as starting material, only homocoupling product was observed by GC-MS, but no product $\mathbf{6}$ was detected. Anisole and meta-xylene were both efficiently oxidized and coupled with pyrazole, although the corresponding products were isolated as a mixture of inseparable regioisomers ( 7 and 8 , respectively), with a higher selectivity for the ortho-coupled regioisomer in the case of 7 and the 1,4-substituted compound for $8 .^{56,59}$ The lower yields can be ascribed to the formation of byproducts derived from homocoupling or oxidation of benzylic positions. Various substituted anisole-derivatives bearing formyl, ester, acetyl, and amide functionalities served as competent coupling partners as well (9-12, 50-80\% yields). Arenes bearing only electronwithdrawing moieties, e.g., acetophenone (13), did not lead to any product formation, which can be attributed to the high oxidation potential of the arene.

Similarly, we investigated the scope of the azole coupling partner (Scheme 2, azole scope). Alkyl-bearing pyrazoles 
Scheme 2. Substrate Scope for the Electrochemical Dehydrogenative C-N Coupling between Arenes and Azoles in a Microflow Reactor ${ }^{a}$
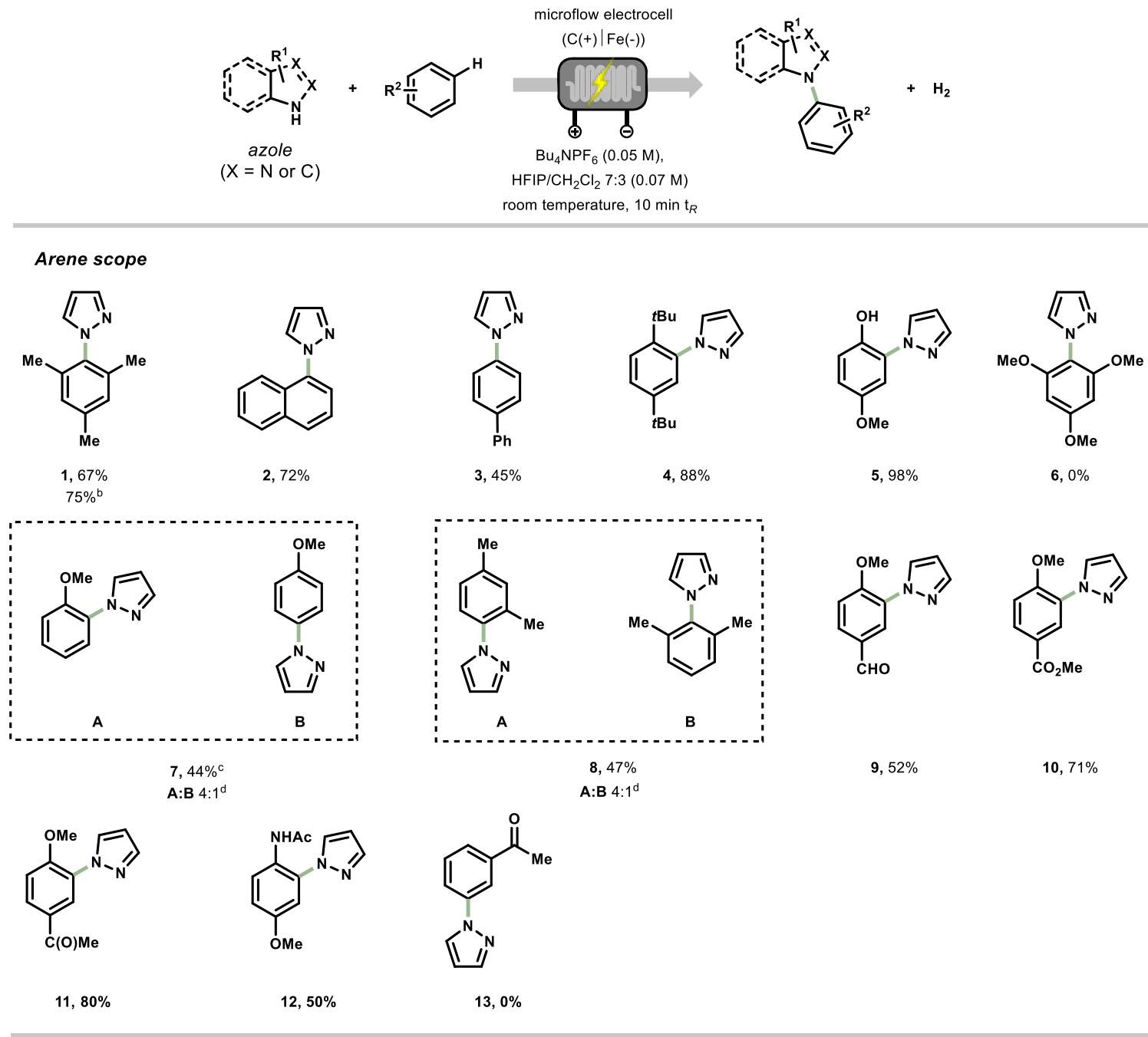

Azole scope

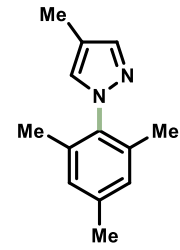

$14,77 \%$

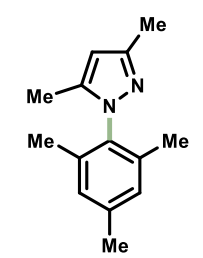

$15,68 \%$

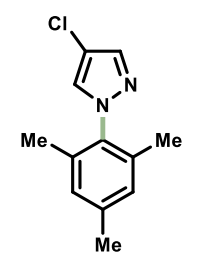

$16,79 \%$

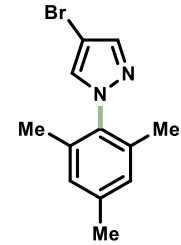

$17,50 \%$

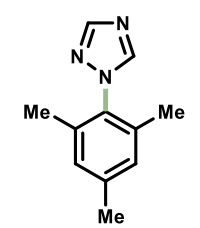

18, $67 \%$

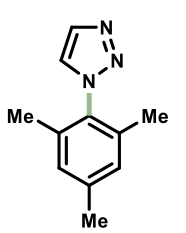

$19,72 \%$

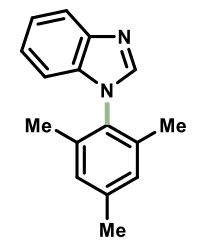

20, $20 \%$

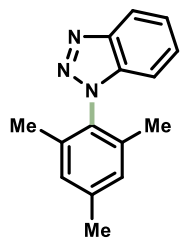

21, $63 \%$

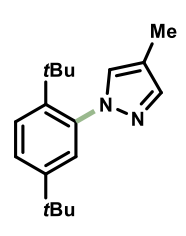

22, $73 \%$<smiles>CC(C)(C)c1ccc(C(C)(C)C)c(-n2ccnn2)c1</smiles>

23, $54 \%$<smiles>Cc1ccc(C)c(-n2nnc3ccccc32)c1</smiles>

24, $47 \%$

${ }^{a}$ Reaction conditions: The feed contains an azole $(0.67 \mathrm{mmol})$, an arene (6.0 equiv), $\mathrm{Bu}_{4} \mathrm{NPF}_{6}(0.05 \mathrm{M})$ in $10 \mathrm{~mL}$ of $\mathrm{HFIP} / \mathrm{CH}_{2} \mathrm{Cl}_{2} 7: 3$. The residence time was set at $10 \mathrm{~min}$, and the system was kept at room temperature with $I=20-30 \mathrm{~mA}\left(0.71-1.1 \mathrm{~mA} \mathrm{~cm}{ }^{-2}\right)$. Reported yields are those obtained after column chromatography. ${ }^{b}$ On a $1.54 \mathrm{mmol}$ scale $\left(219 \mathrm{mg}\right.$ of product collected). ${ }^{c}$ The product was prepared in TFE/MeOH $4: 1$ $(0.067 \mathrm{M})$ using $\mathrm{LiClO}_{4}(0.1 \mathrm{M})$ as a supporting electrolyte. ${ }^{d}$ Regioisomeric ratio measured by ${ }^{1} \mathrm{H}$ NMR of the pure product. 
provided the targeted cross-coupled products in good yields (14-15, 68-77\% yields), showing again no particular sensitivity to steric hindrance (e.g., 15). Pyrazoles decorated with halogens were also suitable nucleophiles (16-17, 65$78 \%$ yields), providing functional handles in the target molecule to enable further diversification using classical cross-coupling strategies. ${ }^{69}$ The electrochemical coupling reaction with triazoles afforded products 18 and 19 in comparable yields to those obtained with pyrazoles $(67-72 \%$ yields). When benzimidazole was employed, product 20 was isolated in $20 \%$ yield, whereas the $\mathrm{C}-\mathrm{N}$ coupled product $\mathbf{2 1}$ derived from mesitylene and benzotriazole was obtained in $65 \%$ yield. Finally, various azole nucleophiles were combined with the sterically hindered 1,4-di-tert-butylbenzene affording the targeted products in synthetically useful yields (22-24, $47-73 \%$ yields).

On the basis of our observations and literature data, ${ }^{56,59}$ we propose the following mechanism to be operative in the electrochemical flow reactor (Scheme 3): the arene is oxidized

\section{Scheme 3. Plausible Mechanism for the Electrochemical} Dehydrogenative Azolation of Arenes

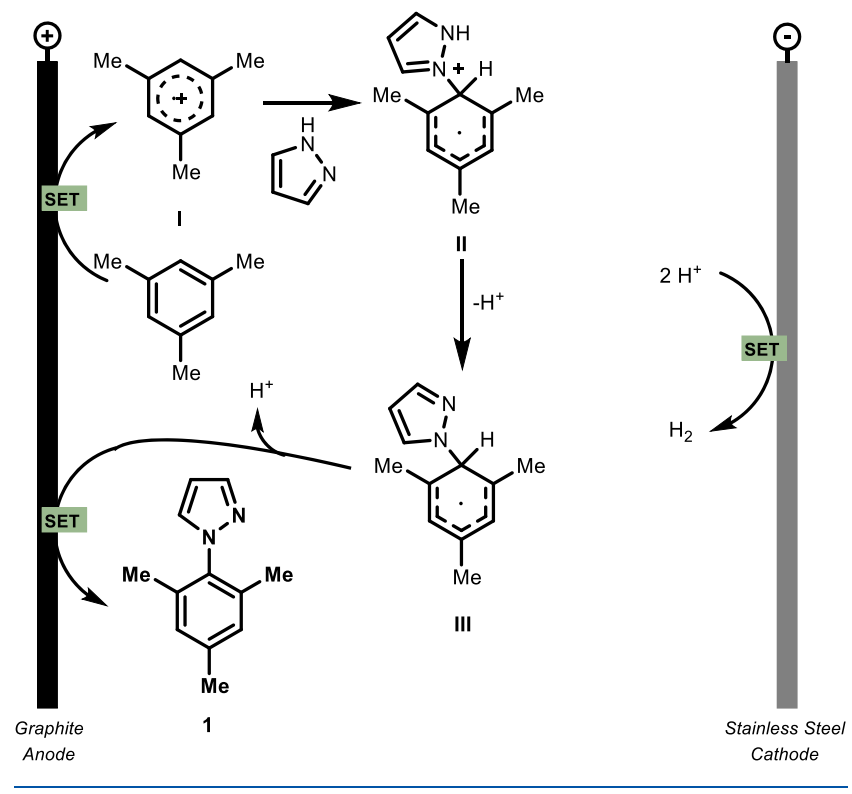

at the graphite anode $(+2.07$ vs saturated calomel electrode (SCE) for mesitylene), ${ }^{70}$ affording the aryl radical cation $\mathbf{I}$. This species can be subsequently attacked by the nucleophilic azole, leading to the formation of the new $\mathrm{C}-\mathrm{N}$ bond. Through a deprotonation step, II will generate the radical species III, which will finally afford the azolated product 1, after losing a second proton and an electron. Concerning the cathodic reaction, protons are reduced to form molecular hydrogen as a synthetically useful byproduct. ${ }^{71}$ This mechanism is also supported by experimental observations, such as the formation of homocoupled products of the arene observed by GC-MS. However, at this stage, we cannot completely rule out the oxidation of both the arene and the azole, which would lead to the product through a radical-radical coupling as suggested by others. ${ }^{57}$ However, due to the high oxidation potential of pyrazole $(+2.21$ vs saturated calomel electrode $(\mathrm{SCE})),{ }^{70}$ we believe this latter scenario is rather unlikely under our reaction conditions for at least the majority of the presented substrates.
In conclusion, we reported the first electrochemical azolation of arenes in flow. The $\mathrm{C}-\mathrm{H}$ functionalization protocol displays a broad scope, reaches high yields in only $10 \mathrm{~min}$, and does not require the addition of any homogeneous catalysts to forge the targeted carbon-nitrogen bond. Given its operational simplicity and reduced reaction times, we anticipate that this electrochemical azolation strategy will find use in modern medicinal chemistry settings.

\section{EXPERIMENTAL SECTION}

All reagents and solvents were used as received without further purification. Reagents and solvents were bought from Sigma-Aldrich, TCI, and Fluorochem. Technical solvents were bought from VWR International and Biosolve and were used as received. All capillary tubing and microfluidic fittings were purchased from IDEX Health \& Science. Disposable syringes were from BD Discardit II or NORMJECT, purchased from VWR Scientific. Syringe pumps were purchased from Chemix Inc. model Fusion 200 Touch. Product isolation was performed manually, using silica (60, F254, Merck). TLC analysis was performed using silica on aluminum foils TLC plates (F254, Supelco Sigma-Aldrich) with visualization under ultraviolet light $(254$ and $365 \mathrm{~nm}) .{ }^{1} \mathrm{H}(400 \mathrm{MHz})$ and ${ }^{13} \mathrm{C}(100$ $\mathrm{MHz}$ ) spectra were recorded at an ambient temperature using a BrukerAvance 400. ${ }^{1} \mathrm{H}$ NMR spectra are reported in parts per million (ppm) downfield relative to $\mathrm{CDCl}_{3}(7.26 \mathrm{ppm})$, and all ${ }^{13} \mathrm{C}$ NMR spectra are reported in ppm relative to $\mathrm{CDCl}_{3}(77.16 \mathrm{ppm})$, unless stated otherwise. NMR spectra use the following abbreviations to describe the multiplicity: $\mathrm{s}=$ singlet, $\mathrm{d}=$ doublet, $\mathrm{t}=$ triplet, $\mathrm{q}=$ quartet, $\mathrm{p}=$ pentet, $\mathrm{h}=$ hextet, hept $=$ heptet, $\mathrm{m}=$ multiplet, $\mathrm{dd}=$ double doublet, $\mathrm{td}=$ triple doublet. NMR data were processed using the MestReNova 9.0.1 software package. Known products were characterized by comparing to the corresponding ${ }^{1} \mathrm{H}$ NMR and ${ }^{13} \mathrm{C}$ NMR from literature. GC analyses were performed on a GC-MS combination (Shimadzu GC-2010 Plus coupled to a Mass Spectrometer; Shimadzu GCMS-QP 2010 Ultra) with an autosampler unit (AOC-20i, Shimadzu). Melting points were determined with a Buchi B-560 capillary melting point apparatus in open capillaries and are uncorrected. The names of all products were generated using the PerkinElmer ChemBioDraw Ultra v.18.0. software package. For all electrochemical continuous flow reactions, a homemade flow cell was used, together with a Velleman LABPS3005D power supply. The cell consists of a working electrode and a counter electrode, with a PTFE (Polytetrafluoroethylene) gasket $(0.25 \mathrm{~mm}$ thickness $)$ containing microchannels in between. The material used for the electrodes were the stainless steel electrode (316L) and the Graphite AC-K800 premium grade (purchased by AgieCharmilles). The active reactor volume is $700 \mu \mathrm{L}$. This results in an undivided electrochemical cell. In the cell, direct contact between the electrode surface and the reaction mixture is established. The reaction mixture is pumped through the system via a syringe pump and is collected in a glass vial. All the technical data of the electrochemical microreactor are reported elsewhere. 65

General Procedure A: Electrochemical C-N Coupling in Flow. The heteroarene $(0.665 \mathrm{mmol})$, tetrabutylammonium hexafluorophosphate $\left(\mathrm{Bu}_{4} \mathrm{NPF}_{6}, 0.05 \mathrm{M}, 194 \mathrm{mg}\right)$, and the arene, if solid, (3-6 equiv) were dissolved in $10 \mathrm{~mL}$ of stock solution $(7: 3 \mathrm{v} / \mathrm{v}$ HFIP/DCM). In the case that the arene was liquid, the heteroarene and the electrolyte were first dissolved in $5 \mathrm{~mL}$ of stock solution, and then the arene was added. Finally, the solution was brought up to 10 $\mathrm{mL}$. The mixture was sonicated until homogeneous and taken up in a $10 \mathrm{~mL}$ disposable syringe. The solution was pumped through the electrochemical reactor with a fixed flow rate of $0.07 \mathrm{~mL} / \mathrm{min}$ to give a residence time of $10 \mathrm{~min}$ in the active part of the reactor, which was equipped with a graphite anode and steel cathode. After applying the appropriate current, based on the results of a previous voltammogram, the first fraction corresponding to the first $20 \mathrm{~min}$ was discarded. The reaction mixture was then collected in a vial, and after an additional 45-70 $\mathrm{min}$, the reaction was stopped. The power supply was turned off, and the reactor was washed with $\mathrm{CH}_{3} \mathrm{CN}(10$ at $0.5 \mathrm{~mL} / \mathrm{min})$. 
The crude mixture was evaporated and purified using silica gel column chromatography.

General Procedure B: Electrochemical C-N Coupling in Flow. The heteroarene $(0.665 \mathrm{mmol})$, lithium perchlorate $\left(\mathrm{LiClO}_{4}\right.$, $0.1 \mathrm{M}, 107 \mathrm{mg}$ ), and the arene, if solid, (3-6 equiv) were dissolved in $10 \mathrm{~mL}$ of stock solution $(4: 1 \mathrm{v} / \mathrm{v}$ TFE/MeOH$)$. In case that the arene was liquid, the heteroarene and the electrolyte were first dissolved in 5 $\mathrm{mL}$ of stock solution, the arene was added, and finally, the solution was brought up to $10 \mathrm{~mL}$. The mixture was sonicated until homogeneous and taken in a $10 \mathrm{~mL}$ disposable syringe. The solution was pumped through the electrochemical setup with a fixed flow rate of $0.07 \mathrm{~mL} / \mathrm{min}$ to give a residence time of $10 \mathrm{~min}$ in the active part of the reactor, which was equipped with a graphite anode and steel cathode. After applying the appropriate current, based on the results of a previous voltammogram, the first fraction corresponding to the first $20 \mathrm{~min}$ was discarded. The reaction mixture was then collected in a vial, and after an appropriate time $(45-70 \mathrm{~min})$, the reaction was stopped. The power supply was turned off, and the reactor was washed with $\mathrm{CH}_{3} \mathrm{CN}$ (10 at $0.5 \mathrm{~mL} / \mathrm{min}$, see Supplementary Information for cleaning procedures). The crude mixture was evaporated and purified using silica gel column chromatography.

1-Mesityl-(1H-pyrazole) (1). Following continuous-flow general procedure $\mathrm{B}(20 \mathrm{~mA}), 4.0 \mathrm{~mL}$ of the mixture was collected (theoretical yield $=49 \mathrm{mg}$ ). The reaction mixture was purified by flash chromatography on silica (cyclohexane to cyclohexane/ethyl acetate $97: 3$ ) to give a white solid ( $33 \mathrm{mg}$, $67 \%$ yield). The analytical data correspond to the reported ones in literature. ${ }^{58}{ }^{1} \mathrm{H}$ NMR $(400$ $\left.\mathrm{MHz}, \mathrm{CDCl}_{3}\right): \delta 7.72(\mathrm{~d}, J=1.8 \mathrm{~Hz}, 1 \mathrm{H}), 7.43(\mathrm{~d}, J=2.3 \mathrm{~Hz}, 1 \mathrm{H})$, $6.94(\mathrm{~s}, 2 \mathrm{H}), 6.43(\mathrm{t}, J=2.1 \mathrm{~Hz}, 1 \mathrm{H}), 2.33(\mathrm{~s}, 3 \mathrm{H}), 1.96(\mathrm{~s}, 6 \mathrm{H})$. ${ }^{13} \mathrm{C}\left\{{ }^{1} \mathrm{H}\right\}$ NMR $\left(101 \mathrm{MHz}, \mathrm{CDCl}_{3}\right): \delta 140.0,138.8,137.0,136.0$, 131.0, 128.9, 105.8, 21.2, 17.3.

1-(Naphthalen-1-yl)-(1H-pyrazole) (2). Following the general procedure A $(20 \mathrm{~mA}), 3.0 \mathrm{~mL}$ of the mixture was collected (theoretical yield $=38.7 \mathrm{mg}$ ). The reaction mixture was purified by flash chromatography on silica (cyclohexane to cyclohexane/ethyl acetate 9:1) to give a colorless oil ( $28 \mathrm{mg}, 72 \%$ yield). The analytical data correspond to the reported ones in literature. ${ }^{56}{ }^{1} \mathrm{H}$ NMR (400 $\left.\mathrm{MHz}, \mathrm{CDCl}_{3}\right): \delta 7.94-7.92(\mathrm{~m}, 2 \mathrm{H}), 7.86(\mathrm{~d}, J=1.9 \mathrm{~Hz}, 1 \mathrm{H}), 7.82-$ $7.79(\mathrm{~m}, 2 \mathrm{H}), 7.57-7.49(\mathrm{~m}, 4 \mathrm{H}), 6.55(\mathrm{t}, J=2.1 \mathrm{~Hz}, 1 \mathrm{H}) .{ }^{13} \mathrm{C}\left\{{ }^{1} \mathrm{H}\right\}$ $\mathrm{NMR}\left(101 \mathrm{MHz}, \mathrm{CDCl}_{3}\right): \delta 140.8,137.4,134.4,131.8,129.3,129.1$, 128.2, 127.4, 126.8, 125.2, 123.4, 123.3, 106.7 .

1-([1,1'-Biphenyl]-4-yl)-(1H-pyrazole) (3). Following the general procedure A $(15 \mathrm{~mA}), 3.8 \mathrm{~mL}$ of the mixture was collected (theoretical yield $=55.6 \mathrm{mg}$ ). The reaction mixture was purified by flash chromatography on silica (cyclohexane to cyclohexane/ethyl acetate $4: 1)$ to give a yellowish oil $(25 \mathrm{mg}, 45 \%$ yield $)$. The analytical data correspond to the reported ones in literature. ${ }^{59}{ }^{1} \mathrm{H}$ NMR (400 $\left.\mathrm{MHz}, \mathrm{CDCl}_{3}\right): \delta 7.97(\mathrm{~d}, J=2.5 \mathrm{~Hz}, 1 \mathrm{H}), 7.81-7.73(\mathrm{~m}, 3 \mathrm{H}), 7.71-$ $7.65(\mathrm{~m}, 2 \mathrm{H}), 7.65-7.58(\mathrm{~m}, 2 \mathrm{H}), 7.46(\mathrm{dd}, J=8.4,6.8 \mathrm{~Hz}, 2 \mathrm{H})$, $7.42-7.33(\mathrm{~m}, 1 \mathrm{H}), 6.50(\mathrm{t}, J=2.1 \mathrm{~Hz}, 1 \mathrm{H}) .{ }^{13} \mathrm{C}\left\{{ }^{1} \mathrm{H}\right\}$ NMR $(101$ $\left.\mathrm{MHz}, \mathrm{CDCl}_{3}\right): \delta 141.3,140.2,139.5,139.4,129.0,128.2,127.6$, 127.1, 126.8, 119.6, 107.8.

1-(2,5-Di-tert-butylphenyl)-(1H-pyrazole) (4). Following the general procedure A $(25 \mathrm{~mA}), 4.0 \mathrm{~mL}$ of the mixture was collected (theoretical yield $=68.1 \mathrm{mg}$ ). The reaction mixture was purified by flash chromatography on silica (cyclohexane to cyclohexane/ethyl acetate 9:1) to give a white solid (60 mg, $88 \%$ yield). Mp: $47.5-48$ ${ }^{\circ} \mathrm{C} .{ }^{1} \mathrm{H}$ NMR $\left(400 \mathrm{MHz}, \mathrm{CDCl}_{3}\right): \delta 7.58(\mathrm{~d}, J=1.8 \mathrm{~Hz}, 1 \mathrm{H}), 7.45(\mathrm{~d}$, $J=2.3 \mathrm{~Hz}, 1 \mathrm{H}), 7.41(\mathrm{~d}, J=8.5 \mathrm{~Hz}, 1 \mathrm{H}), 7.33(\mathrm{dd}, J=8.5,2.3 \mathrm{~Hz}$, $1 \mathrm{H}), 6.98(\mathrm{~d}, J=2.3 \mathrm{~Hz}, 1 \mathrm{H}), 6.31(\mathrm{t}, J=2.1 \mathrm{~Hz}, 1 \mathrm{H}), 1.21(\mathrm{~s}, 9 \mathrm{H})$, $1.06(\mathrm{~s}, 9 \mathrm{H}) .{ }^{13} \mathrm{C}\left\{{ }^{1} \mathrm{H}\right\}$ NMR $\left(101 \mathrm{MHz}, \mathrm{CDCl}_{3}\right): \delta 149.5,144.0$, 139.2, 139.1, 132.5, 127.7, 127.2, 126.4, 105.8, 35.4, 34.3, 31.4, 31.2. HRMS (ESI) $m / z[M+H]^{+}$calcd for $\mathrm{C}_{17} \mathrm{H}_{25} \mathrm{~N}_{2}, 257.2018$; found, 257.2005.

4-Methoxy-2-(1H-pyrazol-1-yl)phenol (5). Following the general procedure A $(30 \mathrm{~mA}), 3.6 \mathrm{~mL}$ of the mixture was collected (theoretical yield $=45.5 \mathrm{mg}$ ). The reaction mixture was purified by flash chromatography on silica (cyclohexane/ethyl acetate 9:1 to 1:1) to give a white solid (45 mg, 98\% yield). The analytical data correspond to the reported ones in literature. ${ }^{57}{ }^{1} \mathrm{H}$ NMR $(400 \mathrm{MHz}$,
$\left.\mathrm{CDCl}_{3}\right): \delta 7.96(\mathrm{~d}, J=2.6 \mathrm{~Hz}, 1 \mathrm{H}), 7.72(\mathrm{~d}, J=1.9 \mathrm{~Hz}, 1 \mathrm{H}), 7.03(\mathrm{~d}$, $J=8.9 \mathrm{~Hz}, 1 \mathrm{H}), 6.92(\mathrm{~d}, J=2.9 \mathrm{~Hz}, 1 \mathrm{H}), 6.76(\mathrm{dd}, J=8.9,2.8 \mathrm{~Hz}$, $1 \mathrm{H}), 6.49(\mathrm{t}, J=2.3 \mathrm{~Hz}, 1 \mathrm{H}), 3.80(\mathrm{~s}, 3 \mathrm{H}) .{ }^{13} \mathrm{C}\left\{{ }^{1} \mathrm{H}\right\}$ NMR $(101$ $\left.\mathrm{MHz}, \mathrm{CDCl}_{3}\right): \delta 152.7,143.3,139.2,126.9,124.9,119.4,112.8$, 107.0, 104.5, 56.1.

1-(2-Methoxyphenyl)-(1H-pyrazole (7A) and 1-(4-Methoxyphenyl)-(1H-pyrazole) (7B). Following the general procedure B $(20 \mathrm{~mA})$, $2.4 \mathrm{~mL}$ of the mixture was collected (theoretical yield $=27.8 \mathrm{mg}$ ). The reaction mixture was purified by flash chromatography on silica (cyclohexane to cyclohexane/ethyl acetate 97:3) to give a yellowish oil (12 mg, 44\%, A/B 4:1). The analytical data correspond to the reported ones in literature. ${ }^{72}$ Compound $7 \mathrm{~A}^{1} \mathrm{H}$ NMR $(400 \mathrm{MHz}$, $\left.\mathrm{CDCl}_{3}\right): \delta 8.03(\mathrm{~d}, J=2.4 \mathrm{~Hz}, 1 \mathrm{H}), 7.72(\mathrm{~m}, 2 \mathrm{H}), 7.30(\mathrm{td}, J=7.9$, $1.7 \mathrm{~Hz}, 1 \mathrm{H}), 7.06-7.03(\mathrm{~m}, 2 \mathrm{H}), 6.43(\mathrm{t}, J=2.1 \mathrm{~Hz}, 1 \mathrm{H}), 3.88(\mathrm{~s}$, $3 \mathrm{H}) .{ }^{13} \mathrm{C}\left\{{ }^{1} \mathrm{H}\right\}$ NMR $\left(101 \mathrm{MHz}, \mathrm{CDCl}_{3}\right.$, mixture of $\mathbf{A}$ and $\left.\mathbf{B}\right): \delta$ $158.3,151.4,140.7,140.2,131.7,129.9,128.1,126.9,125.4,121.3$, 121.0, 114.6, 112.4, 107.3, 106.3, 56.1, 55.7. Compound 7B ${ }^{1} \mathrm{H}$ NMR $\left(400 \mathrm{MHz}, \mathrm{CDCl}_{3}\right): \delta 7.82(\mathrm{~d}, J=2.4 \mathrm{~Hz}, 1 \mathrm{H}), 7.69(\mathrm{~d}, J=1.8 \mathrm{~Hz}$, $1 \mathrm{H}), 7.61-7.54(\mathrm{~m}, 2 \mathrm{H}), 6.98-6.93(\mathrm{~m}, 2 \mathrm{H}), 6.44(\mathrm{~m}, 1 \mathrm{H}), 3.84(\mathrm{~s}$, $3 \mathrm{H}) .{ }^{13} \mathrm{C}\left\{{ }^{1} \mathrm{H}\right\} \mathrm{NMR}\left(101 \mathrm{MHz}, \mathrm{CDCl}_{3}\right.$, mixture of $\mathbf{A}$ and $\left.\mathbf{B}\right)$ 158.3, $151.4,140.7,140.2$, 131.7, 129.9, 128.1, 126.9, 125.4, 121.3, 121.0, 114.6, 112.4, 107.3, 106.3, 56.1, 55.7.

1-(2,4-Dimethylphenyl)-(1H-pyrazole (8A) and 1-(2,6-Dimethylphenyl)-(1H-pyrazole) (8B). Following the general procedure A (15 $\mathrm{mA}$ ), $4.5 \mathrm{~mL}$ of the mixture was collected (theoretical yield $=51.5$ $\mathrm{mg}$ ). The reaction mixture was purified by flash chromatography on silica (cyclohexane to cyclohexane/ethyl acetate 9:1) to give a yellowish oil (24 mg, 47\%, A/B 4:1). The analytical data correspond to the reported ones in literature. ${ }^{58}$ Compound $8 \mathbf{A}^{1} \mathrm{H}$ NMR (400 $\mathrm{MHz}_{\mathrm{CDCl}}$ ): $\delta 7.73(\mathrm{~s}, 1 \mathrm{H}), 7.59-7.58(\mathrm{~m}, 1 \mathrm{H}), 7.22(\mathrm{~d}, J=7.9$ $\mathrm{Hz}, 1 \mathrm{H}), 7.14(\mathrm{~s}, 1 \mathrm{H}), 7.09(\mathrm{~d}, J=8.1 \mathrm{~Hz}, 1 \mathrm{H}), 6.44(\mathrm{~s}, 1 \mathrm{H}), 2.39(\mathrm{~s}$, $3 \mathrm{H}), 2.21(\mathrm{~s}, 3 \mathrm{H}) .{ }^{13} \mathrm{C}\left\{{ }^{1} \mathrm{H}\right\}$ NMR $\left(101 \mathrm{MHz}, \mathrm{CDCl}_{3}\right.$, mixture of $\mathbf{A}$ and B): $\delta 140.1,138.5,137.7,136.4,133.6,132.0,130.8,129.1,128.3$, 127.2, 126.1, 106.1, 21.2, 18.0, 17.4. Compound 8B ${ }^{1} \mathrm{H}$ NMR (399 $\left.\mathrm{MHz}, \mathrm{CDCl}_{3}\right): \delta 7.76(\mathrm{~s}, 1 \mathrm{H}), 7.48(\mathrm{~s}, 1 \mathrm{H}), 7.28(\mathrm{~s}, 2 \mathrm{H}), 7.16(\mathrm{~s}$ $1 \mathrm{H}), 6.47(\mathrm{~s}, 1 \mathrm{H}), 2.02(\mathrm{~s}, 6 \mathrm{H}) .{ }^{13} \mathrm{C}\left\{{ }^{1} \mathrm{H}\right\} \operatorname{NMR}\left(101 \mathrm{MHz}, \mathrm{CDCl}_{3}\right.$, mixture of $\mathbf{A}$ and $\mathbf{B}): \delta 140.1,138.5,137.7,136.4,133.6,132.0,130.8$, $129.1,128.3,127.2,126.1,106.1,21.2,18.0,17.4$.

4-Methoxy-3-(1H-pyrazol-1-yl)benzaldehyde (9). Following the general procedure $\mathrm{A}(20 \mathrm{~mA}), 4.0 \mathrm{~mL}$ of the mixture was collected (theoretical yield $=53.7 \mathrm{mg}$ ). The reaction mixture was purified by flash chromatography on silica (cyclohexane/ethyl acetate 9:1 to 4:1) to give a yellow oil (28 mg, $52 \%$ yield). $\left.{ }^{1} \mathrm{H} \mathrm{NMR} \mathrm{(400} \mathrm{MHz,} \mathrm{CDCl}_{3}\right)$ : $\delta 9.95(\mathrm{~s}, 1 \mathrm{H}), 8.29(\mathrm{~d}, J=2.1 \mathrm{~Hz}, 1 \mathrm{H}), 8.07(\mathrm{~d}, J=2.5 \mathrm{~Hz}, 1 \mathrm{H}), 7.87$ $(\mathrm{dd}, J=8.5,2.1 \mathrm{~Hz}, 1 \mathrm{H}), 7.74(\mathrm{~d}, J=1.9 \mathrm{~Hz}, 1 \mathrm{H}), 7.18(\mathrm{~d}, J=8.6 \mathrm{~Hz}$, $1 \mathrm{H}), 6.46(\mathrm{t}, J=2.1 \mathrm{~Hz}, 1 \mathrm{H}), 4.00(\mathrm{~s}, 3 \mathrm{H}) .{ }^{13} \mathrm{C}\left\{{ }^{1} \mathrm{H}\right\}$ NMR $(100$ $\left.\mathrm{MHz}, \mathrm{CDCl}_{3}\right): \delta 190.4,155.9,140.7,131.6,130.3,130.2,129.3$, 127.4, 112.5, 106.9, 56.6. HRMS (ESI) $\mathrm{m} / z[\mathrm{M}+\mathrm{H}]^{+}$calcd for $\mathrm{C}_{11} \mathrm{H}_{11} \mathrm{~N}_{2} \mathrm{O}_{2}$, 203.0821; found, 203.0816.

Methyl 4-Methoxy-3-(1H-pyrazol-1-yl)-benzoate (10). Following the general procedure $\mathrm{A}(20 \mathrm{~mA}), 4.3 \mathrm{~mL}$ of the mixture was collected (theoretical yield $=66 \mathrm{mg}$ ). The reaction mixture was purified by flash chromatography on silica (cyclohexane to cyclohexane/ethyl acetate 9:1) to give a white solid ( $47 \mathrm{mg}, 71 \%$ yield). Mp: $95-96{ }^{\circ} \mathrm{C} .{ }^{1} \mathrm{H}$ NMR $\left(399 \mathrm{MHz}, \mathrm{CDCl}_{3}\right): \delta 8.40(\mathrm{~s}, 1 \mathrm{H}), 8.03-$ $8.01(\mathrm{~m}, 2 \mathrm{H}), 7.73(\mathrm{~s}, 1 \mathrm{H}), 7.08(\mathrm{~d}, J=8.7 \mathrm{~Hz}, 1 \mathrm{H}), 6.44(\mathrm{~s}, 1 \mathrm{H})$, 3.95 (s, 3H), $3.90(\mathrm{~s}, 3 \mathrm{H}) .{ }^{13} \mathrm{C}\left\{{ }^{1} \mathrm{H}\right\} \operatorname{NMR}\left(100 \mathrm{MHz}, \mathrm{CDCl}_{3}\right): \delta$ $166.3,154.9,140.5,131.6,130.0,129.5,126.9,123.4,111.8,106.6$, 56.3, 52.2. HRMS (ESI) $m / z[\mathrm{M}+\mathrm{H}]^{+}$calcd for $\mathrm{C}_{12} \mathrm{H}_{13} \mathrm{~N}_{2} \mathrm{O}_{3}$, 233.0926; found, 233.0924 .

1-(4-Methoxy-3-(1H-pyrazol-1-yl)phenyl)ethan-1-one (11). Following the general procedure $\mathrm{A}(30 \mathrm{~mA}), 4.2 \mathrm{~mL}$ of the mixture was collected (theoretical yield $=60.3 \mathrm{mg}$ ). The reaction mixture was purified by flash chromatography on silica (cyclohexane to cyclohexane/ethyl acetate 9:1) to give a white solid (48 mg, $80 \%$ yield). Mp 71.5-72.3 ${ }^{\circ} \mathrm{C} .{ }^{1} \mathrm{H}$ NMR $\left(400 \mathrm{MHz}, \mathrm{CDCl}_{3}\right): \delta 8.31$ (d, $J=2.2$ $\mathrm{Hz}, 1 \mathrm{H}), 8.03(\mathrm{~d}, J=2.5 \mathrm{~Hz}, 1 \mathrm{H}), 7.94(\mathrm{dd}, J=8.7,2.3 \mathrm{~Hz}, 1 \mathrm{H}), 7.72$ $(\mathrm{d}, J=1.8 \mathrm{~Hz}, 1 \mathrm{H}), 7.08(\mathrm{~d}, J=8.7 \mathrm{~Hz}, 1 \mathrm{H}), 6.44(\mathrm{t}, J=2.2 \mathrm{~Hz}, 1 \mathrm{H})$, $3.95(\mathrm{~s}, 3 \mathrm{H}), 2.58(\mathrm{~s}, 3 \mathrm{H}) .{ }^{13} \mathrm{C}\left\{{ }^{1} \mathrm{H}\right\}$ NMR $\left(101 \mathrm{MHz}^{\mathrm{C}} \mathrm{CDCl}_{3}\right): \delta$ 196.4 , 154.9, 140.5, 131.6, 130.7, 129.5, 128.5, 126.0, 111.9, 106.7, 
56.3, 26.6. HRMS (ESI) $m / z[\mathrm{M}+\mathrm{H}]^{+}$calcd for $\mathrm{C}_{12} \mathrm{H}_{13} \mathrm{~N}_{2} \mathrm{O}_{2}$, 217.0977; found, 217.0965 .

N-(4-Methoxy-2-(1H-pyrazol-1-yl)phenyl)acetamide (12). Following the general procedure A $(30 \mathrm{~mA}), 4.6 \mathrm{~mL}$ of the mixture was collected (theoretical yield $=70 \mathrm{mg}$ ). The reaction mixture was purified by flash chromatography on silica (cyclohexane/ethyl acetate $1: 1)$ to give a yellow oil ( $34 \mathrm{mg}, 50 \%$ yield). The analytical data correspond to the reported ones in literature. ${ }^{57}{ }^{1} \mathrm{H}$ NMR $(400 \mathrm{MHz}$, $\left.\mathrm{CDCl}_{3}\right): \delta 9.91(\mathrm{~s}, 1 \mathrm{H}), 8.28(\mathrm{~d}, J=9.0 \mathrm{~Hz}, 1 \mathrm{H}), 7.78(\mathrm{~d}, J=2.2 \mathrm{~Hz}$, $2 \mathrm{H}), 6.89(\mathrm{dd}, J=9.0,2.8 \mathrm{~Hz}, 1 \mathrm{H}), 6.84(\mathrm{~d}, J=2.8 \mathrm{~Hz}, 1 \mathrm{H}), 6.49(\mathrm{t}, J$ $=2.2 \mathrm{~Hz}, 1 \mathrm{H}), 3.82(\mathrm{~s}, 3 \mathrm{H}), 2.10(\mathrm{~s}, 3 \mathrm{H}) .{ }^{13} \mathrm{C}\left\{{ }^{1} \mathrm{H}\right\} \mathrm{NMR}(101 \mathrm{MHz}$, $\left.\mathrm{CDCl}_{3}\right): \delta 168.4,156.1,141.2,130.3,130.2,124.9,124.7,112.7$, 109.0, 107.3, 55.8, 24.9.

1-Mesityl-4-methyl-(1H-pyrazole) (14). Following the general procedure A $(20 \mathrm{~mA}), 3.5 \mathrm{~mL}$ of the mixture was collected (theoretical yield $=46.5 \mathrm{mg}$ ). The reaction mixture was purified by flash chromatography on silica (cyclohexane to cyclohexane/ethyl acetate 9:1) to give a colorless oil ( $36 \mathrm{mg}, 77 \%$ yield). ${ }^{1} \mathrm{H}$ NMR (399 $\left.\mathrm{MHz}, \mathrm{CDCl}_{3}\right): \delta 7.50(\mathrm{~s}, 1 \mathrm{H}), 7.15(\mathrm{~s}, 1 \mathrm{H}), 6.86(\mathrm{~s}, 2 \mathrm{H}), 2.25(\mathrm{~s}$, $3 \mathrm{H}), 2.11(\mathrm{~s}, 3 \mathrm{H}), 1.91(\mathrm{~s}, 6 \mathrm{H}) .{ }^{13} \mathrm{C}\left\{{ }^{1} \mathrm{H}\right\} \mathrm{NMR}\left(100 \mathrm{MHz}, \mathrm{CDCl}_{3}\right)$ : $\delta 140.5,138.6,137.2,136.0,129.6,128.8,116.2,21.2,17.3,9.0$ HRMS (ESI) $m / z[M+H]^{+}$calcd for $\mathrm{C}_{13} \mathrm{H}_{17} \mathrm{~N}_{2}, 201.1392$; found, 201.1383.

1-Mesityl-3,5-dimethyl-(1H-pyrazole) (15). Following the general procedure A $(10 \mathrm{~mA}), 3.0 \mathrm{~mL}$ of the mixture was collected (theoretical yield $=42.7 \mathrm{mg}$ ). The reaction mixture was purified by flash chromatography on silica (cyclohexane to cyclohexane/ethyl acetate 95:5) to give a colorless oil ( $29 \mathrm{mg}, 68 \%$ yield). ${ }^{1} \mathrm{H}$ NMR $\left(400 \mathrm{MHz}, \mathrm{CDCl}_{3}\right): \delta 6.92(\mathrm{~s}, 2 \mathrm{H}), 5.95(\mathrm{~s}, 1 \mathrm{H}), 2.31(\mathrm{~s}, 3 \mathrm{H}), 2.28$ (s, 3H), $1.96(\mathrm{~s}, 3 \mathrm{H}), 1.92(\mathrm{~s}, 6 \mathrm{H}) .{ }^{13} \mathrm{C}\left\{{ }^{1} \mathrm{H}\right\} \mathrm{NMR}(101 \mathrm{MHz}$, $\left.\mathrm{CDCl}_{3}\right): \delta 148.6,140.1,138.6,136.5,135.4,128.8,104.5,21.2,17.3$, 13.8, 11.0. HRMS (ESI) $\mathrm{m} / z[\mathrm{M}+\mathrm{H}]^{+}$calcd for $\mathrm{C}_{14} \mathrm{H}_{19} \mathrm{~N}_{2}$, 215.1548; found, 215.1538

4-Chloro-1-mesityl-(1H-pyrazole) (16). Following the general procedure A $(20 \mathrm{~mA}), 3.8 \mathrm{~mL}$ of the mixture was collected (theoretical yield $=55.7 \mathrm{mg}$ ). The reaction mixture was purified by flash chromatography on silica (cyclohexane to cyclohexane/ethyl acetate 9:1) to give a dark yellow oil (44 mg, 79\% yield). The analytical data correspond to the reported ones in literature. ${ }^{58}{ }^{1} \mathrm{H}$ NMR $\left(400 \mathrm{MHz}, \mathrm{CDCl}_{3}\right): \delta 7.65(\mathrm{~s}, 1 \mathrm{H}), 7.43(\mathrm{~s}, 1 \mathrm{H}), 6.94(\mathrm{~s}, 2 \mathrm{H})$, $2.33(\mathrm{~s}, 3 \mathrm{H}), 1.99(\mathrm{~s}, 6 \mathrm{H}) \cdot{ }^{13} \mathrm{C}\left\{{ }^{1} \mathrm{H}\right\} \operatorname{NMR}\left(101 \mathrm{MHz}, \mathrm{CDCl}_{3}\right): \delta$ 139.4, 138.6, 136.6, 135.8, 129.0, 128.9, 110.5, 21.2, 17.3.

1-Mesityl-4-bromo-(1H-pyrazole) (17). Following the general procedure A $(10 \mathrm{~mA}), 4.2 \mathrm{~mL}$ of the mixture was collected (theoretical yield $=74 \mathrm{mg}$ ). The reaction mixture was purified by flash chromatography on silica (cyclohexane to cyclohexane/ethyl acetate $98: 2$ ) to give a yellow oil ( $37 \mathrm{mg}, 50 \%$ yield). ${ }^{58}{ }^{1} \mathrm{H}$ NMR (399 $\left.\mathrm{MHz}, \mathrm{CDCl}_{3}\right): \delta 7.68(\mathrm{~s}, 1 \mathrm{H}), 7.46(\mathrm{~s}, 1 \mathrm{H}), 6.94(\mathrm{~s}, 2 \mathrm{H}), 2.33(\mathrm{~s}$, $3 \mathrm{H}), 1.98(\mathrm{~s}, 6 \mathrm{H}) \cdot{ }^{13} \mathrm{C}\left\{{ }^{1} \mathrm{H}\right\}$ NMR $\left(100 \mathrm{MHz}, \mathrm{CDCl}_{3}\right): \delta 140.8$, 139.4, 136.6, 135.8, 131.1, 129.0, 93.7, 21.2, 17.4.

1-Mesityl-(1H-1,2,4-triazole) (18). Following the general procedure $\mathrm{A}(20 \mathrm{~mA}), 4.6 \mathrm{~mL}$ of the mixture was collected (theoretical yield $=56.3 \mathrm{mg}$ ). The reaction mixture was purified by flash chromatography on silica (cyclohexane/ethyl acetate $4: 1$ to $1: 1$ ) to give a white solid (38 mg, 67\% yield). ${ }^{73}{ }^{1} \mathrm{H}$ NMR (400 MHz, $\left.\mathrm{CDCl}_{3}\right): \delta 8.21(\mathrm{~s}, 1 \mathrm{H}), 8.19(\mathrm{~s}, 1 \mathrm{H}), 6.98(\mathrm{~s}, 2 \mathrm{H}), 2.35(\mathrm{~s}, 3 \mathrm{H}), 1.97$ $(\mathrm{s}, 6 \mathrm{H}) .{ }^{13} \mathrm{C}\left\{{ }^{1} \mathrm{H}\right\}$ NMR $\left(101 \mathrm{MHz}, \mathrm{CDCl}_{3}\right): \delta 151.9,144.4,140.2$, 135.6, 133.0, 129.3, 21.2, 17.4.

1-Mesityl-(1H-1,2,3-triazole) (19). Following the general procedure A $(20 \mathrm{~mA}), 5.0 \mathrm{~mL}$ of the mixture was collected (theoretical yield $=62.2 \mathrm{mg}$ ). The reaction mixture was purified by flash chromatography on silica (cyclohexane/ethyl acetate 9:1 to $4: 1$ ) to give a white solid ( $45 \mathrm{mg}, 72 \%$ yield). $\mathrm{Mp}: 188-189{ }^{\circ} \mathrm{C} .{ }^{1} \mathrm{H}$ NMR $\left(400 \mathrm{MHz}, \mathrm{CDCl}_{3}\right): \delta 7.87(\mathrm{~s}, 1 \mathrm{H}), 7.62(\mathrm{~s}, 1 \mathrm{H}), 6.98(\mathrm{~s}, 2 \mathrm{H}), 2.34$ (s, 3H), $1.93(\mathrm{~s}, 6 \mathrm{H}) \cdot{ }^{13} \mathrm{C}\left\{{ }^{1} \mathrm{H}\right\} \mathrm{NMR}\left(101 \mathrm{MHz}, \mathrm{CDCl}_{3}\right): \delta 140.1$, $135.2,133.7,133.5,129.2,125.5,21.2,17.3$. HRMS (ESI) $m / z[\mathrm{M}+$ $\mathrm{H}]^{+}$calcd for $\mathrm{C}_{11} \mathrm{H}_{14} \mathrm{~N}_{3}, 188.1188$; found, 188.1187 .

1-Mesityl-(1H-benzo[d]imidazole) (20). Following the general procedure A $(20 \mathrm{~mA}), 3.8 \mathrm{~mL}$ of the mixture was collected (theoretical yield $=59.6 \mathrm{mg}$ ). The reaction mixture was purified by flash chromatography on silica (cyclohexane to cyclohexane/ethyl acetate $9: 1)$ to give a yellow oil $(12 \mathrm{mg}, 20 \%$ yield). The analytical data correspond to the reported ones in literature. ${ }^{74}{ }^{1} \mathrm{H}$ NMR (400 $\left.\mathrm{MHz}, \mathrm{CDCl}_{3}\right): \delta 7.89(\mathrm{~d}, J=8.0 \mathrm{~Hz}, 1 \mathrm{H}), 7.87(\mathrm{~s}, 1 \mathrm{H}), 7.35-7.24$ $(\mathrm{m}, 2 \mathrm{H}), 7.05(\mathrm{~s}, 2 \mathrm{H}), 7.03(\mathrm{~d}, J=7.7 \mathrm{~Hz}, 1 \mathrm{H}), 2.39(\mathrm{~s}, 3 \mathrm{H}), 1.92(\mathrm{~s}$, $6 \mathrm{H}) .{ }^{13} \mathrm{C}\left\{{ }^{1} \mathrm{H}\right\} \mathrm{NMR}\left(101 \mathrm{MHz}, \mathrm{CDCl}_{3}\right): \delta 143.4,143.2,139.4,136.4$, $134.3,131.2,129.5,123.6,122.5,120.5,110.3,21.3,17.6$.

1-Mesityl-(1H-benzo[d][1,2,3]triazole) (21). Following the general procedure A $(25 \mathrm{~mA}), 3.4 \mathrm{~mL}$ of the mixture was collected (theoretical yield $=53.6 \mathrm{mg}$ ). The reaction mixture was purified by flash chromatography on silica (cyclohexane to cyclohexane/ethyl acetate 9:1) to give a yellowish oil ( $34 \mathrm{mg}, 63 \%$ yield). The analytical data correspond to the reported ones in literature. ${ }^{74}{ }^{1} \mathrm{H}$ NMR (400 $\left.\mathrm{MHz}, \mathrm{CDCl}_{3}\right): \delta 8.16(\mathrm{~d}, J=8.2,1 \mathrm{H}), 7.44$ (dddd, $J=24.5,8.0,6.9$, $1.1 \mathrm{~Hz}, 2 \mathrm{H}), 7.20(\mathrm{~d}, J=8.2,1 \mathrm{H}), 7.06(\mathrm{~s}, 2 \mathrm{H}), 2.40(\mathrm{~s}, 3 \mathrm{H}), 1.87(\mathrm{~s}$, $6 \mathrm{H}) .{ }^{13} \mathrm{C}\left\{{ }^{1} \mathrm{H}\right\}$ NMR $\left(101 \mathrm{MHz}, \mathrm{CDCl}_{3}\right): \delta 145.5,140.3,136.3,134.0$, $131.7,129.4,128.1,124.1,120.2,109.9,21.3,17.5$.

1-(2,5-Di-tert-butylphenyl)-4-methyl-(1H-pyrazole) (22). Following the general procedure $\mathrm{A}(20 \mathrm{~mA}), 4.7 \mathrm{~mL}$ of the mixture was collected (theoretical yield $=84.5 \mathrm{mg}$ ). The reaction mixture was purified by flash chromatography on silica (cyclohexane to cyclohexane/ethyl acetate $98: 2)$ to give a white solid (62 mg, $73 \%$ yield). Mp: $94-94.5{ }^{\circ} \mathrm{C} .{ }^{1} \mathrm{H}$ NMR $\left(400 \mathrm{MHz}, \mathrm{CDCl}_{3}\right): \delta 7.50-7.44(\mathrm{~m}$, $2 \mathrm{H}), 7.40(\mathrm{dd}, \mathrm{J}=8.5,2.3 \mathrm{~Hz}, 1 \mathrm{H}), 7.31(\mathrm{~s}, 1 \mathrm{H}), 7.06(\mathrm{~d}, \mathrm{~J}=2.3 \mathrm{~Hz}$, $1 \mathrm{H}), 2.17(\mathrm{~s}, 3 \mathrm{H}), 1.29(\mathrm{~s}, 9 \mathrm{H}), 1.17(\mathrm{~s}, 9 \mathrm{H}) .{ }^{13} \mathrm{C}\left\{{ }^{1} \mathrm{H}\right\}$ NMR $(100$ $\left.\mathrm{MHz}, \mathrm{CDCl}_{3}\right): \delta 149.4,144.1,139.7,139.4,131.4,127.6,127.3$, $126.3,116.3,35.5,34.3,31.5,31.3,9.0$. HRMS (ESI) $m / z[\mathrm{M}+\mathrm{H}]^{+}$ calcd for $\mathrm{C}_{18} \mathrm{H}_{27} \mathrm{~N}_{2}$, 271.2174; found, 271.2165 .

1-(2,5-Di-tert-butylphenyl)-(1H-1,2,3-triazole) (23). Following the general procedure $\mathrm{A}(20 \mathrm{~mA}), 3.0 \mathrm{~mL}$ of the mixture was collected (theoretical yield $=51.3 \mathrm{mg}$ ). The reaction mixture was purified by flash chromatography on silica (cyclohexane to cyclohexane/ethyl acetate $9: 1)$ to give a white solid ( $28 \mathrm{mg}, 54 \%$ yield). Mp: $115-115.5$ ${ }^{\circ} \mathrm{C} .{ }^{1} \mathrm{H}$ NMR $\left(400 \mathrm{MHz}, \mathrm{CDCl}_{3}\right): \delta 7.84(\mathrm{~s}, 1 \mathrm{H}), 7.74(\mathrm{~s}, 1 \mathrm{H}), 7.55$ $(\mathrm{d}, J=8.5 \mathrm{~Hz}, 1 \mathrm{H}), 7.49(\mathrm{dd}, J=8.5,2.2 \mathrm{~Hz}, 1 \mathrm{H}), 7.01(\mathrm{~d}, J=2.2 \mathrm{~Hz}$, $1 \mathrm{H}), 1.30(\mathrm{~s}, 9 \mathrm{H}), 1.12(\mathrm{~s}, 9 \mathrm{H}) .{ }^{13} \mathrm{C}\left\{{ }^{1} \mathrm{H}\right\} \operatorname{NMR}\left(101 \mathrm{MHz}, \mathrm{CDCl}_{3}\right)$ : $\delta$ 150.0, 143.8, 135.4, 133.3, 128.1, 127.6, 127.4, 126.6, 35.6, 34.4, 31.5, 31.2. HRMS (ESI) $m / z[\mathrm{M}+\mathrm{H}]^{+}$calcd for $\mathrm{C}_{16} \mathrm{H}_{24} \mathrm{~N}_{3}$, 258.1970; found, 258.1975.

1-(2,5-Di-tert-butylphenyl)-(1H-benzo[d][1,2,3]triazole) (24). Following the general procedure $\mathrm{A}(20 \mathrm{~mA}), 4.3 \mathrm{~mL}$ of the mixture was collected (theoretical yield $=87.9 \mathrm{mg}$ ). The reaction mixture was purified by flash chromatography on silica (cyclohexane to cyclohexane/ethyl acetate 9:1) to give a white solid (42 mg, 47\% yield). $\mathrm{Mp}:=122-123^{\circ} \mathrm{C} .{ }^{1} \mathrm{H}$ NMR $\left(400 \mathrm{MHz}, \mathrm{CDCl}_{3}\right): \delta 8.06(\mathrm{~d}, J=8.3$ $\mathrm{Hz}, 1 \mathrm{H}), 7.57(\mathrm{~d}, J=8.6 \mathrm{~Hz}, 1 \mathrm{H}), 7.47(\mathrm{dd}, J=8.5,2.3 \mathrm{~Hz}, 1 \mathrm{H}), 7.40$ (ddd, $J=8.1,6.9,1.1 \mathrm{~Hz}, 1 \mathrm{H}), 7.33(\mathrm{ddd}, J=8.0,6.9,1.1 \mathrm{~Hz}, 1 \mathrm{H})$, $7.23-7.15(\mathrm{~m}, 1 \mathrm{H}), 6.96(\mathrm{~d}, J=2.3 \mathrm{~Hz}, 1 \mathrm{H}), 1.21(\mathrm{~s}, 9 \mathrm{H}), 1.00(\mathrm{~s}$, 9H). ${ }^{13} \mathrm{C}\left\{{ }^{1} \mathrm{H}\right\} \mathrm{NMR}\left(101 \mathrm{MHz}, \mathrm{CDCl}_{3}\right): \delta 150.3,145.4,145.3,136.0$, 133.9, 128.5, 128.0, 127.6, 127.1, 124.1, 119.9, 110.7, 35.5, 34.4, 31.6, 31.2. HRMS (ESI) $m / z[M+H]^{+}$calcd for $\mathrm{C}_{20} \mathrm{H}_{26} \mathrm{~N}_{3}, 308.2127$; found, 308.2114 .

\section{ASSOCIATED CONTENT}

\section{Supporting Information}

The Supporting Information is available free of charge at https://pubs.acs.org/doi/10.1021/acs.joc.1c01409.

Description of reaction setups, radical trapping experiments, and spectral data of all products (PDF)

\section{AUTHOR INFORMATION}

\section{Corresponding Author}

Timothy Noël - Van't Hoff Institute for Molecular Sciences (HIMS), University of Amsterdam, 9041098 XH Amsterdam, The Netherlands; 이이이.org/0000-00023107-6927; Email: t.noel@uva.nl 


\section{Authors}

Laura Buglioni - Department of Chemical Engineering and Chemistry, Micro Flow Chemistry \& Synthetic Methodology, Eindhoven University of Technology, 5612 AZ Eindhoven, The Netherlands; (1) orcid.org/0000-0002-7337-1772

Marko Beslać - Department of Chemical Engineering and Chemistry, Micro Flow Chemistry \& Synthetic Methodology, Eindhoven University of Technology, 5612 AZ Eindhoven, The Netherlands

Complete contact information is available at:

https://pubs.acs.org/10.1021/acs.joc.1c01409

\section{Notes}

The authors declare no competing financial interest.

\section{ACKNOWLEDGMENTS}

L.B. would like to acknowledge the European Union for a Marie Sklodowska Curie IF Grant (ELECTROSULF, grant no. 840724).

\section{REFERENCES}

(1) Khanna, I. K.; Yu, Y.; Huff, R. M.; Weier, R. M.; Xu, X.; Koszyk, F. J.; Collins, P. W.; Cogburn, J. N.; Isakson, P. C.; Koboldt, C. M.; Masferrer, J. L.; Perkins, W. E.; Seibert, K.; Veenhuizen, A. W.; Yuan, J.; Yang, D.-C.; Zhang, Y. Y. Selective Cyclooxygenase-2 Inhibitors: Heteroaryl Modified 1,2-Diarylimidazoles Are Potent, Orally Active Antiinflammatory Agents. J. Med. Chem. 2000, 43 (16), 3168-3185.

(2) Hili, R.; Yudin, A. K. Making Carbon-Nitrogen Bonds in Biological and Chemical Synthesis. Nat. Chem. Biol. 2006, 2 (6), 284-287.

(3) Zhang, L.; Peng, X.-M.; Damu, G. L. V.; Geng, R.-X.; Zhou, C.$\mathrm{H}$. Comprehensive Review in Current Developments of ImidazoleBased Medicinal Chemistry. Med. Res. Rev. 2014, 34 (2), 340-437.

(4) Vitaku, E.; Smith, D. T.; Njardarson, J. T. Analysis of the Structural Diversity, Substitution Patterns, and Frequency of Nitrogen Heterocycles among U.S. FDA Approved Pharmaceuticals. J. Med. Chem. 2014, 57 (24), 10257-10274.

(5) Vicentini, C. B.; Romagnoli, C.; Andreotti, E.; Mares, D. Synthetic Pyrazole Derivatives as Growth Inhibitors of Some Phytopathogenic Fungi. J. Agric. Food Chem. 2007, 55 (25), 10331-10338.

(6) Wolfe, J. P.; Wagaw, S.; Marcoux, J.-F.; Buchwald, S. L. Rational Development of Practical Catalysts for Aromatic Carbon-Nitrogen Bond Formation. Acc. Chem. Res. 1998, 31 (12), 805-818.

(7) Hartwig, J. F. Evolution of a Fourth Generation Catalyst for the Amination and Thioetherification of Aryl Halides. Acc. Chem. Res. 2008, 41 (11), 1534-1544.

(8) Sambiagio, C.; Marsden, S. P.; Blacker, A. J.; McGowan, P. C. Copper Catalysed Ullmann Type Chemistry: From Mechanistic Aspects to Modern Development. Chem. Soc. Rev. 2014, 43 (10), $3525-3550$.

(9) He, J.; Shigenari, T.; Yu, J.-Q. Palladium(0)/PAr 3 -Catalyzed Intermolecular Amination of $\mathrm{C}\left(\mathrm{sp}^{3}\right)-\mathrm{H}$ Bonds: Synthesis of $\beta$-Amino Acids. Angew. Chem., Int. Ed. 2015, 54 (22), 6545-6549.

(10) Sadhu, P.; Punniyamurthy, T. Copper(II)-Mediated Regioselective N-Arylation of Pyrroles, Indoles, Pyrazoles and Carbazole via Dehydrogenative Coupling. Chem. Commun. 2016, 52 (13), 28032806.

(11) Pawar, G. G.; Wu, H.; De, S.; Ma, D. Copper(I) Oxide/ N, N' -Bis[(2-Furyl)Methyl]Oxalamide-Catalyzed Coupling of (Hetero)Aryl Halides and Nitrogen Heterocycles at Low Catalytic Loading. Adv. Synth. Catal. 2017, 359 (10), 1631-1636.

(12) Surry, D. S.; Buchwald, S. L. Biaryl Phosphane Ligands in Palladium-Catalyzed Amination. Angew. Chem., Int. Ed. 2008, 47 (34), 6338-6361.
(13) Collet, F.; Dodd, R. H.; Dauban, P. Catalytic C-H Amination: Recent Progress and Future Directions. Chem. Commun. 2009, No. 34, 5061-5074.

(14) Armstrong, A.; Collins, J. C. Direct Azole Amination: C-H Functionalization as a New Approach to Biologically Important Heterocycles. Angew. Chem., Int. Ed. 2010, 49 (13), 2282-2285.

(15) Pan, J.; Su, M.; Buchwald, S. L. Palladium(0)-Catalyzed Intermolecular Amination of Unactivated $\mathrm{C}\left(\mathrm{sp}^{3}\right)-\mathrm{H}$ Bonds. Angew. Chem., Int. Ed. 2011, 50 (37), 8647-8651.

(16) Ueda, S.; Su, M.; Buchwald, S. L. Highly $\mathrm{N}_{2}$-Selective Palladium-Catalyzed Arylation of 1,2,3-Triazoles. Angew. Chem., Int. Ed. 2011, 50 (38), 8944-8947.

(17) Ueda, S.; Su, M.; Buchwald, S. L. Completely N 1 -Selective Palladium-Catalyzed Arylation of Unsymmetric Imidazoles: Application to the Synthesis of Nilotinib. J. Am. Chem. Soc. 2012, 134 (1), $700-706$.

(18) Ueda, S.; Buchwald, S. L. Catalyst-Controlled Chemoselective Arylation of 2-Aminobenzimidazoles. Angew. Chem., Int. Ed. 2012, 51 (41), 10364-10367.

(19) Thirunavukkarasu, V. S.; Kozhushkov, S. I.; Ackermann, L. C-H Nitrogenation and Oxygenation by Ruthenium Catalysis. Chem. Commun. 2014, 50 (1), 29-39.

(20) Louillat, M.-L.; Patureau, F. W. Oxidative C-H Amination Reactions. Chem. Soc. Rev. 2014, 43 (3), 901-910.

(21) Louillat-Habermeyer, M.-L.; Jin, R.; Patureau, F. W. $\mathrm{O}_{2^{-}}$ Mediated Dehydrogenative Amination of Phenols. Angew. Chem., Int. Ed. 2015, 54 (13), 4102-4104.

(22) Yi, H.; Zhang, G.; Wang, H.; Huang, Z.; Wang, J.; Singh, A. K.; Lei, A. Recent Advances in Radical C-H Activation/Radical CrossCoupling. Chem. Rev. 2017, 117 (13), 9016-9085.

(23) Bambal, R.; Hanzlik, R. P. Synthesis of N. Epsilon.-(pBromophenyl)-L-Lysine and N. Tau.-(p-Bromophenyl)-L-Histidine as Models for Adducts of Bromobenzene 3,4-Oxide to Protein. Observation of an Unusual Pd-Catalyzed N. Tau. to N. Pi.-Aryl Substituent Migration. J. Org. Chem. 1994, 59 (4), 729-732.

(24) Ji, P.; Atherton, J. H.; Page, M. I. The Kinetics and Mechanisms of Aromatic Nucleophilic Substitution Reactions in Liquid Ammonia. J. Org. Chem. 2011, 76 (9), 3286-3295.

(25) Zhou, Q.; Hong, X.; Cui, H.-Z.; Huang, S.; Yi, Y.; Hou, X.-F. The Construction of $\mathrm{C}-\mathrm{N}, \mathrm{C}-\mathrm{O}$, and $\mathrm{C}\left(\mathrm{sp}^{2}\right)-\mathrm{C}\left(\mathrm{sp}^{3}\right)$ Bonds from Fluorine-Substituted 2-Aryl Benzazoles for Direct Synthesis of N-, O-, C-Functionalized 2-Aryl Benzazole Derivatives. J. Org. Chem. 2018, 83 (12), 6363-6372.

(26) Wu, W.-B.; Huang, J.-M. Highly Regioselective C-N Bond Formation through C-H Azolation of Indoles Promoted by Iodine in Aqueous Media. Org. Lett. 2012, 14 (23), 5832-5835.

(27) Tanimoto, K.; Okai, H.; Oka, M.; Ohkado, R.; Iida, H. Aerobic Oxidative C-H Azolation of Indoles and One-Pot Synthesis of Azolyl Thioindoles by Flavin-Iodine-Coupled Organocatalysis. Org. Lett. 2021, 23 (6), 2084-2088.

(28) Gonda, Z.; Novák, Z. Transition-Metal-Free N -Arylation of Pyrazoles with Diaryliodonium Salts. Chem. - Eur. J. 2015, 21 (47), 16801-16806.

(29) Teskey, C. J.; Sohel, S. M. A.; Bunting, D. L.; Modha, S. G.; Greaney, M. F. Domino N -/ C -Arylation via In Situ Generation of a Directing Group: Atom-Efficient Arylation Using Diaryliodonium Salts. Angew. Chem., Int. Ed. 2017, 56 (19), 5263-5266.

(30) Romero, N. A.; Margrey, K. A.; Tay, N. E.; Nicewicz, D. A. SiteSelective Arene C-H Amination via Photoredox Catalysis. Science (Washington, DC, U. S.) 2015, 349 (6254), 1326-1330.

(31) Niu, L.; Yi, H.; Wang, S.; Liu, T.; Liu, J.; Lei, A. Photo-Induced Oxidant-Free Oxidative C-H/N-H Cross-Coupling between Arenes and Azoles. Nat. Commun. 2017, 8 (1), 14226.

(32) Das, S.; Natarajan, P.; König, B. Teaching Old Compounds New Tricks: DDQ-Photocatalyzed C-H Amination of Arenes with Carbamates, Urea, and N-Heterocycles. Chem. - Eur. J. 2017, 23 (72), $18161-18165$.

(33) Margrey, K. A.; McManus, J. B.; Bonazzi, S.; Zecri, F.; Nicewicz, D. A. Predictive Model for Site-Selective Aryl and 
Heteroaryl C-H Functionalization via Organic Photoredox Catalysis. J. Am. Chem. Soc. 2017, 139 (32), 11288-11299.

(34) Twilton, J.; Le, C. Chip; Zhang, P.; Shaw, M. H.; Evans, R. W.; MacMillan, D. W. C. The Merger of Transition Metal and Photocatalysis. Nat. Rev. Chem. 2017, 1 (7), 52.

(35) Samanta, S.; Ravi, C.; Rao, S. N.; Joshi, A.; Adimurthy, S. Visible-Light-Promoted Selective C-H Amination of Heteroarenes with Heteroaromatic Amines under Metal-Free Conditions. Org. Biomol. Chem. 2017, 15 (45), 9590-9594.

(36) Zheng, M.; Ghosh, I.; König, B.; Wang, X. Metal-Free Semiconductor Photocatalysis for Sp $2 \mathrm{C}-\mathrm{H}$ Functionalization with Molecular Oxygen. ChemCatChem 2019, 11 (2), 703-706.

(37) Kärkäs, M. D. Electrochemical Strategies for C-H Functionalization and C-N Bond Formation. Chem. Soc. Rev. 2018, 47 (15), $5786-5865$.

(38) Hou, Z.; Mao, Z.; Zhao, H.; Melcamu, Y. Y.; Lu, X.; Song, J.; $\mathrm{Xu}, \mathrm{H}$. Electrochemical C-H/N-H Functionalization for the Synthesis of Highly Functionalized (Aza)Indoles. Angew. Chem., Int. Ed. 2016, 55 (32), 9168-9172.

(39) Morofuji, T.; Shimizu, A.; Yoshida, J. Electrochemical C-H Amination: Synthesis of Aromatic Primary Amines via N-Arylpyridinium Ions. J. Am. Chem. Soc. 2013, 135 (13), 5000-5003.

(40) Morofuji, T.; Shimizu, A.; Yoshida, J. Heterocyclization Approach for Electrooxidative Coupling of Functional Primary Alkylamines with Aromatics. J. Am. Chem. Soc. 2015, 137 (31), 9816-9819.

(41) Hayashi, R.; Shimizu, A.; Song, Y.; Ashikari, Y.; Nokami, T.; Yoshida, J. Metal-Free Benzylic C-H Amination via Electrochemically Generated Benzylaminosulfonium Ions. Chem. - Eur. J. 2017, 23 (1), 61-64.

(42) Wesenberg, L. J.; Diehl, E.; Zähringer, T. J. B.; Dörr, C.; Schollmeyer, D.; Shimizu, A.; Yoshida, J.; Hellmich, U. A.; Waldvogel, S. R. Metal-Free Twofold Electrochemical C-H Amination of Activated Arenes: Application to Medicinally Relevant Precursor Synthesis. Chem. - Eur. J. 2020, 26 (72), 17574-17580.

(43) Ošeka, M.; Laudadio, G.; van Leest, N. P.; Dyga, M.; Bartolomeu, A. de A.; Gooßen, L. J.; de Bruin, B.; de Oliveira, K. T.; Noël, T. Electrochemical Aziridination of Internal Alkenes with Primary Amines. Chem. 2021, 7 (1), 255-266.

(44) Lin, M.-Y.; Xu, K.; Jiang, Y.-Y.; Liu, Y.-G.; Sun, B.-G.; Zeng, C.C. Intermolecular Electrochemical C $\left(\mathrm{sp}^{3}\right)-\mathrm{H} / \mathrm{N}-\mathrm{H}$ Cross-Coupling of Xanthenes with N-Alkoxyamides: Radical Pathway Mediated by Ferrocene as a Redox Catalyst. Adv. Synth. Catal. 2018, 360 (8), $1665-1672$.

(45) Hou, Z.; Liu, D.; Xiong, P.; Lai, X.; Song, J.; Xu, H. SiteSelective Electrochemical Benzylic C-H Amination. Angew. Chem., Int. Ed. 2021, 60 (6), 2943-2947.

(46) Sperry, J. B.; Wright, D. L. The Application of Cathodic Reductions and Anodic Oxidations in the Synthesis of Complex Molecules. Chem. Soc. Rev. 2006, 35 (7), 605.

(47) Yan, M.; Kawamata, Y.; Baran, P. S. Synthetic Organic Electrochemical Methods Since 2000: On the Verge of a Renaissance. Chem. Rev. 2017, 117 (21), 13230-13319.

(48) Ghosh, M.; Shinde, V. S.; Rueping, M. A Review of Asymmetric Synthetic Organic Electrochemistry and Electrocatalysis: Concepts, Applications, Recent Developments and Future Directions. Beilstein J. Org. Chem. 2019, 15, 2710-2746.

(49) Kingston, C.; Palkowitz, M. D.; Takahira, Y.; Vantourout, J. C.; Peters, B. K.; Kawamata, Y.; Baran, P. S. A Survival Guide for the "Electro-Curious. Acc. Chem. Res. 2020, 53 (1), 72-83.

(50) Yan, M.; Kawamata, Y.; Baran, P. S. Synthetic Organic Electrochemistry: Calling All Engineers. Angew. Chem., Int. Ed. 2018, 57 (16), 4149-4155.

(51) Morofuji, T.; Shimizu, A.; Yoshida, J. Direct C-N Coupling of Imidazoles with Aromatic and Benzylic Compounds via Electrooxidative C-H Functionalization. J. Am. Chem. Soc. 2014, 136 (12), 4496-4499.

(52) de Robillard, G.; Makni, O.; Cattey, H.; Andrieu, J.; Devillers, C. H. Towards Sustainable Synthesis of Pyren-1-Yl Azoliums via
Electrochemical Oxidative C-N Coupling. Green Chem. 2015, 17 (9), 4669-4679.

(53) Yang, Y.-Z.; Song, R.-J.; Li, J.-H. Intermolecular Anodic Oxidative Cross-Dehydrogenative $\mathrm{C}\left(\mathrm{sp}^{3}\right)-\mathrm{N}$ Bond-Coupling Reactions of Xanthenes with Azoles. Org. Lett. 2019, 21 (9), 3228-3231.

(54) Wan, Z.; Wang, D.; Yang, Z.; Zhang, H.; Wang, S.; Lei, A. Electrochemical Oxidative $\mathrm{C}\left(\mathrm{sp}^{3}\right)-\mathrm{H}$ Azolation of Lactams under Mild Conditions. Green Chem. 2020, 22 (12), 3742-3747.

(55) Yu, Y.; Yuan, Y.; Liu, H.; He, M.; Yang, M.; Liu, P.; Yu, B.; Dong, X.; Lei, A. Electrochemical Oxidative C-H/N-H CrossCoupling for C-N Bond Formation with Hydrogen Evolution. Chem. Commun. 2019, 55 (12), 1809-1812.

(56) Wang, J.-H.; Lei, T.; Nan, X.-L.; Wu, H.-L.; Li, X.-B.; Chen, B.; Tung, C.-H.; Wu, L.-Z. Regioselective Ortho Amination of an Aromatic C-H Bond by Trifluoroacetic Acid via Electrochemistry. Org. Lett. 2019, 21 (14), 5581-5585.

(57) Feng, P.; Ma, G.; Chen, X.; Wu, X.; Lin, L.; Liu, P.; Chen, T. Electrooxidative and Regioselective $\mathrm{C}-\mathrm{H}$ Azolation of Phenol and Aniline Derivatives. Angew. Chem., Int. Ed. 2019, 58 (25), 8400-8404.

(58) Huang, H.; Strater, Z. M.; Rauch, M.; Shee, J.; Sisto, T. J.; Nuckolls, C.; Lambert, T. H. Electrophotocatalysis with a Trisaminocyclopropenium Radical Dication. Angew. Chem., Int. Ed. 2019, 58 (38), 13318-13322.

(59) Zhang, L.; Liardet, L.; Luo, J.; Ren, D.; Grätzel, M.; Hu, X. Photoelectrocatalytic Arene C-H Amination. Nat. Catal. 2019, 2 (4), 366-373.

(60) Folgueiras-Amador, A. A.; Wirth, T. Perspectives in Flow Electrochemistry. J. Flow Chem. 2017, 7 (3-4), 94-95.

(61) Noël, T.; Cao, Y.; Laudadio, G. The Fundamentals Behind the Use of Flow Reactors in Electrochemistry. Acc. Chem. Res. 2019, 52 (10), 2858-2869.

(62) Laudadio, G.; Straathof, N. J. W.; Lanting, M. D.; Knoops, B.; Hessel, V.; Noël, T. An Environmentally Benign and Selective Electrochemical Oxidation of Sulfides and Thiols in a ContinuousFlow Microreactor. Green Chem. 2017, 19 (17), 4061-4066.

(63) Laudadio, G.; Barmpoutsis, E.; Schotten, C.; Struik, L.; Govaerts, S.; Browne, D. L.; Noël, T. Sulfonamide Synthesis through Electrochemical Oxidative Coupling of Amines and Thiols. J. Am. Chem. Soc. 2019, 141 (14), 5664-5668.

(64) Govaerts, S.; Nyuchev, A.; Noel, T. Pushing the Boundaries of $\mathrm{C}-\mathrm{H}$ Bond Functionalization Chemistry Using Flow Technology. J. Flow Chem. 2020, 10 (1), 13-71.

(65) Laudadio, G.; de Smet, W.; Struik, L.; Cao, Y.; Noël, T. Design and Application of a Modular and Scalable Electrochemical Flow Microreactor. J. Flow Chem. 2018, 8 (3), 157-165.

(66) Colomer, I.; Chamberlain, A. E. R.; Haughey, M. B.; Donohoe, T. J. Hexafluoroisopropanol as a Highly Versatile Solvent. Nat. Rev. Chem. 2017, 1 (11), 0088.

(67) Röckl, J. L.; Dörr, M.; Waldvogel, S. R. Electrosynthesis 2.0 in 1,1,1,3,3,3-Hexafluoroisopropanol/Amine Mixtures. ChemElectroChem 2020, 7 (18), 3686-3694.

(68) Ramos-Villaseñor, J. M.; Rodríguez-Cárdenas, E.; Barrera Díaz, C. E.; Frontana-Uribe, B. A. Review-Use of 1,1,1,3,3,3-Hexafluoro2-Propanol (HFIP) Co-Solvent Mixtures in Organic Electrosynthesis. J. ElectroChem. Soc. 2020, 167 (15), 155509.

(69) Johansson Seechurn, C. C. C.; Kitching, M. O.; Colacot, T. J.; Snieckus, V. Palladium-Catalyzed Cross-Coupling: A Historical Contextual Perspective to the 2010 Nobel Prize. Angew. Chem., Int. Ed. 2012, 51 (21), 5062-5085.

(70) Roth, H. G.; Romero, N. A.; Nicewicz, D. A. Experimental and Calculated Electrochemical Potentials of Common Organic Molecules for Applications to Single-Electron Redox Chemistry. Synlett 2016, 27 (05), 714-723.

(71) Cao, Y.; Soares, C.; Padoin, N.; Noël, T. Gas Bubbles Have Controversial Effects on Taylor Flow Electrochemistry. Chem. Eng. J. 2021, 406, 126811.

(72) Sikari, R.; Sinha, S.; Chakraborty, G.; Das, S.; Leest, N. P.; Paul, N. D. C-N Cross-Coupling Reactions Under Mild Conditions Using 
Singlet Di-Radical Nickel(II)-Complexes as Catalyst: N-Arylation and Quinazoline Synthesis. Adv. Synth. Catal. 2019, 361 (18), 4342-4353. (73) Abramovitch, R. A.; Beckert, J. M.; Gibson, H. H.; Belcher, A.; Hundt, G.; Sierra, T.; Olivella, S.; Pennington, W. T.; Solé, A. The 1,2,4-Triazolyl Cation: Thermolytic and Photolytic Studies. J. Org. Chem. 2001, 66 (4), 1242-1251.

(74) Hirano, K.; Biju, A. T.; Glorius, F. Copper-Catalyzed Synthesis of 2-Unsubstituted, N-Substituted Benzimidazoles. J. Org. Chem. 2009, 74 (24), 9570-9572. 